\title{
Audit committee compensation, best practices and audit fees
}

Author:

Bum-Jin Park ${ }^{1}$ (D)

\section{Affiliation:}

${ }^{1}$ Department of Business

Administration,

Soonchunhyang University,

Asan, South Korea

Corresponding author:

Bum-Jin Park,

sunguja@sch.ac.kr

Dates:

Received: 31 Oct. 2018

Accepted: 13 June 2019

Published: 02 Sept. 2019

How to cite this article:

Park, B-J. (2019). Audit

committee compensation,

best practices and audit fees.

South African Journal of

Business Management 50(1),

a1293. https://doi.org/

10.4102/sajbm.v50i1.1293

\section{Copyright:}

(C) 2019. The Authors.

Licensee: AOSIS. This work

is licensed under the

Creative Commons

Attribution License.
Read online:

Scan this QR code with your smart phone or mobile device to read online.
Background: It is extremely important that an audit committee (AC) monitors a company's financial reporting process, and that the committee engages a high-quality auditor to carry this out effectively. Prior research on ACs has paid much attention to the relationship between AC best practices and audit fees (AF). Although compensation is a means of aligning interests between ACs and stakeholders, previous studies have neglected the complementary interaction between AC compensation and compliance with best practices on audit quality.

Objectives: The purpose of this study is to investigate how compensation for ACs affects AF, and how the association is moderated by compliance with best practices to capture effective monitoring.

Method: The regression models are estimated to verify how the relationship between AC compensation and AF is moderated by AC compliance with best practice. Moreover, the logistic regression models are used to investigate how the relationship between $\mathrm{AC}$ compensation and the opportunistic achievement of earnings goals is moderated by AC compliance with best practice.

Results: The findings show a positive association between the levels of compensation AC members receive and AF, which is reinforced in firms that have ACs that comply with all best practices.

Conclusion: The results suggest that highly paid ACs engage high-quality auditors to complement their function of monitoring management and $\mathrm{AC}$ compensation and compliance with best practices are complementary to enhance audit quality. This study thus provides the interesting insights that can be applicable to countries with requirements relating to the compensation schemes for ACs or the formation of the AC.

Keywords: Audit committee best practice; audit fees; audit committee compensation; earnings goals; agency theory.

\section{Introduction}

What resolves the divergence of interests between audit committees (AC) and stakeholders with respect to audit quality? There would be a potential conflict between AC pay-off and the welfare of stakeholders when ACs face economic incentives. This study aims to investigate how AC compensation affects audit fees (AF) and how this relationship is moderated by AC compliance with best practices. The results will provide insights that the compensation schemes for ACs serve as a catalyst to enhance AC effectiveness and it is complementary to AC compliance with best practice guidelines in enhancing audit quality.

In the wake of the Enron accounting scandal, audit quality has received much attention in both the private and public sectors (Knechel, 2015; Loukil, 2014; Park, 2015, 2017; Redmayne, Bradbury, \& Cahan, 2011). With increasing regulatory and market demands for high-quality auditing, considerable attention has been paid to the role of the ACs (Abbott, Parker, Peters, \& Raghunandan, 2003; Abbott, Parker, \& Peters, 2004; Park, 2019; Redmayne et al., 2011).

Audit committees are responsible for overseeing auditor selection, auditing and financial reporting processes (Abbott et al., 2003, 2004) and therefore have interacted with external auditors to monitor managers (Knechel, Krishnan, Pevzner, Shefchik, \& Velury, 2013; Park, 2019). It has been the growth of mandatory AC requirements in many developed countries (Fichtner, 2010). For example, the United States (2002) and Canada (1975) governments require all companies to form ACs composed solely of outside directors, while others require companies to form ACs including at least one (Germany [2009]), two (South Africa [2006]), a majority (Australia [2004]) or more than two-thirds (Korea [2000]) of AC members as outside directors. 
While the majority of studies on ACs have focused only on the relationship between AC best practices and AF which may represent audit quality, there is little research on the interaction between AC compensation, which can align interests of ACs and stakeholders, and compliance with AC best guidelines in determining AF. Audit quality can be promoted when auditors try to reach a higher level of audit assurance by making more efforts to collect audit evidence. However, cost-cutting efforts for auditing could make auditors lead a less sceptical approach to audits by limiting audit plan or scope (Abbott et al., 2003; Beck \& Mauldin, 2014; Christensen, Omer, Sharp, \& Shelley, 2013; Doogar, Rowe, \& Sivadasan, 2015; Huang, Parker, Anderson, \& Lin, 2014; Loukil, 2014; Park, 2019). Thus, ACs responsible for determining AF play a crucial role in enhancing audit quality, and effective $\mathrm{AC}$ is closely associated with the engagement of high-quality auditors.

Drawing on agency theory concerning $\mathrm{AC}^{\prime} \mathrm{s}$ economic incentives, ACs may make decisions about monitoring the management that, from the perspective of stakeholders, are not the best (Archambeault, DeZoort, \& Hermanson, 2008; Fama, 1980; Fama \& Jensen, 1983; Keune \& Johnstone, 2015; Magilke, Mayhew, \& Pike, 2009). Thus, agency problems between ACs ('agent') and stakeholders ('principal') could be alleviated when there are the compensation schemes and requirements for $\mathrm{ACs}$ that can align the interests of the two (Barrier, 2002; Bierstaker, Cohen, DeZoort, \& Hermanson, 2012; Rickling \& Sharma, 2017). There are competing views on the relationship between the compensation for ACs and AC effectiveness. In order for the AC system to meet its intrinsic purpose, a company must have competent professional personnel as AC members and should provide appropriate economic compensation and economic incentive schemes that encourage AC members to do their best. On the other hand, there is a contradictory view that ACs that receive excessive compensation can compromise their independence (Korea Corporate Governance Service [KCGS], 2007). Specifically, two competing views on the relationship between compensation for ACs and AF have been observed. If high compensation leads to a high demand for monitoring the financial reporting process, highly paid ACs would engage high-quality auditors to complement their monitoring roles (Barrier, 2002; Bierstaker et al., 2012; Rickling \& Sharma, 2017). On the other hand, if a high level of compensation results from tolerating managerial opportunistic behaviour, highly paid ACs would engage low-quality auditors to conceal their opportunism (Archambeault et al., 2008; Keune \& Johnstone, 2015; Magilke et al., 2009). However, there has been no attempt to verify the mixed results on the relationship between $\mathrm{AC}$ compensation and $\mathrm{AF}$ by using the moderator of AC compliance with best practice which represents effective $\mathrm{AC}$.

The compliance of AC to all best practice guidelines can be considered as a measure of effective ACs. From prior studies, three best practices are identified for ACs. Firstly, AC members should be outside directors who are independent of management and controlling shareholders (Abbott \& Parker, 2000; Abbott et al., 2003, 2004; Baxter \& Cotter, 2009; Beasley, Carcello, Hermanson, \& Lapides, 2000; Bedard, Chtourou, \& Courteau, 2004; Hamdan, Mushtaha, \& Al-Sartawi, 2015; Klein, 2002; Kusnadi, Leong, Suwardy, \& Wang, 2016; Public Oversight Board [POB], 1993; Sultana, Singh, \& Van der Zahn, 2015; Vlaminck \& Sarens, 2015). Secondly, ACs should include at least one member who has relevant accounting and financial expertise (Abbott et al., 2003, 2004; Baxter \& Cotter, 2009; Blue Ribbon Committee [BRC], 1999; Choi, Jeon, \& Park, 2004; Kusnadi et al., 2016; Sultana et al., 2015; Xie, Davidson, \& DaDalt, 2003). Thirdly, ACs should meet frequently in order to effectively monitor management (Abbott \& Parker, 2000; Abbott et al., 2003, 2004; Baxter \& Cotter, 2009; Beasley et al., 2000; Bedard et al., 2004; BRC, 1999; Goodwin-Steward \& Kent, 2006; Hamdan et al., 2015; National Association of Corporate Directors [NACD], 2000).

In order to fill the gap in the literature, this study is interested in the complementary or countervailing interaction between $\mathrm{AC}$ compensation and compliance with $\mathrm{AC}$ best practices on AF. Taken together, if a positive relationship between AC compensation and AF represents the necessity to monitor the financial reporting process (Barrier, 2002; Bierstaker et al., 2012; Rickling \& Sharma, 2017), this relationship will be strengthened in firms that have ACs complying with all best practices. On the other hand, if a negative relationship between AC compensation and AF is evidence that ACs have compromised their independence (Archambeault et al., 2008; Keune \& Johnstone, 2015; Magilke et al., 2009), this relationship will be attenuated in firms with ACs which comply with all best practices.

The findings show a positive association between the level of compensation for ACs and AF, which is reinforced in firms with ACs which comply with all best practices. These results suggest that highly paid ACs engage high-quality auditors to complement their function of monitoring management and that $\mathrm{AC}$ compensation and compliance with AC best practices are complementary to enhance audit quality.

The contributions this study makes are twofold. Firstly, to my knowledge, this study is the first attempt to examine compensation for ACs and AF, by using the moderating effects of compliance with best practice. Secondly, this study provides new insights into ACs and the compensation schemes that motivate them to play an important role in management monitoring and audit quality.

\section{Background and hypotheses development}

\section{Audit committee compensation and audit fees in Korea}

Over the last three decades, the regulatory and market demands of corporate governance and accounting transparency have increased rapidly on a global scale. In particular, the recommendations of the BRC (1999) emphasise 
that ACs that are responsible for selecting and overseeing auditors have the authority to determine their compensation. It is stipulated in the Sarbanes-Oxley (SOX) Act of 2002. In the wake of this trend, the Korean Commercial Code (KCC), released in 2000, stipulates the formation of ACs.

South Korea provides a unique setting in which to examine the interactive effect of compensation for ACs in relation to their compliance with best practice on AF.

Firstly, because compensation for ACs is determined at annual general meetings (KCC), the process of determining their compensation is not independent of controlling shareholders or management with high ownership. The corporate ownership structure in Asian countries is more concentrated than it is in the developed countries (e.g. the United Kingdom and the United States). In the Korean corporate environment where the separation between ownership and control is relatively unclear, it has been questionable whether the high level of AC compensation can be a clue to ways to limit managers' opportunistic behaviour (Cheng, Su, \& Zhu, 2012; La Porta, Lopez-deSilanes, \& Shleifer, 1999; Ng, 2005). Korea companies should obtain approval from the AC for AF when engaging auditors, which means that the $\mathrm{AC}$ has both direct and indirect influence on AF (Korean Act on External Audit of Stock Companies [KAEASC]). Therefore, effective ACs would put more effort into monitoring the financial reporting process, and prefer high-quality auditors to complement their role.

Secondly, Korean companies pay compensation to ACs in cash only. Regarding the forms of compensation, incentivebased compensation in the form of stock options has the opposite effect on financial reporting quality, depending on their short- and long-term performance, but the effect of cash only compensation on financial reporting quality has no bearing on the length of the compensation period (Barrier, 2002; Bierstaker et al., 2012; Keune \& Johnstone, 2015; Rickling \& Sharma, 2017). Compensation in the form of short-term stock options would make AC members concentrate only on raising their short-term pay-off, but long-term stock options would prevent conflict between financial incentives and the long-term welfare of shareholders (Archambeault et al., 2008; Keune \& Johnstone, 2015; Magilke et al., 2009). In Korea, the effect of ACs' compensation on AF is isolated from the incentives of short- and long-term compensation. Thirdly, in Korea, there are mandatory standards relating to the AC composition. Korean Commercial Code requires only publicly traded firms with assets over 2 trillion Korean won (about USD 1.8 billion, based on the 2018 average exchange rate) to form ACs; more than twothirds of its members should be outside directors, and at least one member should be financial or accounting expertise. That is, some companies have voluntary ACs and thus not all ACs need to follow best practice guidelines. There are no mandatory regulations on the frequency of AC meetings in Korea, but KCGS recommends that they meet at least once each quarter.
In Korean institutional settings, there are competing reviews of the association between compensation for $\mathrm{ACs}$ and AF.

Firstly, high compensation for ACs can be the price (or 'bribes') paid for tolerating managerial opportunistic behaviour. As discussed earlier, the selection and compensation of AC members can be affected by controlling shareholders and management with high ownership; in such a situation, the economic bonding between AC members and managers will be strengthened when managers have opportunistic incentives (Archambeault et al., 2008; Jensen, 1993; Keune \& Johnstone, 2015; Magilke et al., 2009). Archambeault et al. (2008) found that incentive compensation for AC members is positively associated with accounting restatements. Magilke et al. (2009) argued that short-term stock options for ACs lead to aggressive managerial reporting, whereas their long-term incentive compensation is related to conservative managerial reporting. Keune and Johnstone (2015) found that the AC that receives short- or long-term stock options is more likely to tolerate qualitatively significant misstatements. Given this assumption, highly paid ACs would engage relatively low-quality auditors, resulting in lower $\mathrm{AF}$. Secondly, high compensation may result from taking an effective role in monitoring management (Barrier, 2002; Bierstaker et al., 2012; Rickling \& Sharma, 2017). Barrier (2002) argues that a compensation structure motivates AC members to effectively monitor the management. Bierstaker et al. (2012) found that ACs whose compensation includes long-term stock options support the auditors when accounting disagreements occur between management and external auditors, indicating that economic incentive for $\mathrm{AC}$ members to receive long-term compensation is consistent with the long-term welfare of stakeholders. Rickling and Sharma (2017) found that cash-based compensation for AC members is negatively associated with the likelihood of actual earnings exceeding analysts' forecasts, suggesting that high AC compensation makes ACs less tolerant of earnings management to meet or beat analysts' forecasts. Given this assumption, highly paid ACs may lead to high demand for monitoring of the financial reporting process, resulting in higher AF. Taken together, 'rational' compensation schemes for ACs will serve as a safety device, alleviating agency problems between managers and external shareholders. This is a very interesting topic for study in Korea, where compensation for AC members is paid in cash only. Thus, the first hypothesis $\left(\mathrm{H}_{1}\right)$ is:

$\mathbf{H}_{1}$ : There is no relationship between AC compensation and AF.

\section{The moderating effects of audit committee compliance with best practices}

The best practices through which ACs can be effective internal controlling bodies have been noted many times in numerous reports from the United States (BRC, NACD, POB, Securities and Exchange Commission [SEC]). Public Oversight Board (1993) reports that AC effectiveness improves when an AC is composed completely of outside directors. Blue Ribbon Committee (1999) recommends that an 
AC be composed of directors who have financial knowledge and who can understand corporate operations and financial statements, and that it should include at least one member with financial or accounting expertise. Moreover, BRC (1999) and NACD (2000) stress that the frequency of AC meetings can represent the committee's diligence, and thus recommend that ACs meet more than four times each year.

According to these reports, many researchers have analysed how an AC's characteristics affect the effectiveness of its ability to monitor the financial reporting process. Firstly, there is considerable research on the relationship between AC independence and AC effectiveness. Beasley et al. (2000) and Abbott et al. (2004) revealed that either financial statement fraud or restatements are lower when ACs include more outside directors, and Abbott and Parker (2000) showed that ACs composed of only outside directors tend to select industry specialist auditors. A number of empirical studies report only positive associations between AC independence and earnings management, even though they used different national data (Baxter \& Cotter, 2009; Bedard et al., 2004; Hamdan et al., 2015; Klein, 2002; Kusnadi et al., 2016; Vlaminck \& Sarens, 2015). Further, Abbott et al. (2003) showed that there is a positive effect of AC independence on AF. Sultana et al. (2015) found that AC independence is negatively related to audit report lags, suggesting that it is effective also in improving the accounting agreements between management and auditors. Secondly, there are studies into the relationship between AC members' expertise and AC effectiveness. Xie et al. (2003), Choi et al. (2004), Baxter and Cotter (2009) and Kusnadi et al. (2016) provided empirical evidence that earnings management is decreased when ACs include a financial or accounting expert. Abbott et al. (2003) reported that AF are higher when ACs have more than one member with finance or accounting expertise. Moreover, Sultana et al. (2015) reported that audit report lags are shorter when ACs include a member with accounting or financial expertise, indicating that accounting disagreements between management and external auditors are reduced. Thirdly, there is some research into the relationship between the frequency of AC meetings and AC effectiveness. This line of research is based on a premise that the monitoring of ACs for management increases with meeting frequency. Beasley et al. (2000) found that financial statement frauds are higher for firms with ACs that meet less frequently. Abbott and Parker (2000) showed that ACs that meet at least twice annually are more likely to engage industry specialist auditors. Xie et al. (2003), Baxter and Cotter (2009) and Hamdan et al. (2015) argued that the more active an AC is, the less earnings management there is. Abbott et al. (2004) found that companies have less financial restatement when ACs meet more than four times annually and Abbott et al. (2003) and Goodwin-Steward and Kent (2006) showed that $\mathrm{AF}$ are higher as the activities of ACs increase. Moreover, Sharma, Sharma and Ananthanarayanan (2011) found that the positive relationship between the client's economic importance to auditors and earnings management becomes negative in firms where ACs comply with all best practices, suggesting that effective ACs can limit the decrease in earnings quality caused by client importance. Zaman, Hudaib and Haniffa (2011) showed that there is a positive relationship between AC compliance with best practice and $\mathrm{AF}$, indicating that effective ACs prefer high-quality auditors in order to enhance their monitoring functions. Loukil (2014) revealed that ACs that are independent and meet more frequently are more likely to select high-quality auditors. Park (2019) found that managerial influence to reduce AF is more weakened when a voluntary AC complies with best practices. Consequently, each AC characteristic can have not only an individual, but also a composite, effect on the determination of AF. As described in Hypothesis 1, if a highly paid AC prefers high-quality auditors (Barrier, 2002; Bierstaker et al., 2012; Rickling \& Sharma, 2017), there will be a positive association between AC members' compensation level and AF, with this association being more pronounced for firms with ACs which comply with all best practices. The second hypothesis $\left(\mathrm{H}_{2}\right)$ is:

$\mathbf{H}_{2}$ : The relationship between $\mathrm{AC}$ compensation and $\mathrm{AF}$ is more pronounced for firms where ACs comply with all best practices.

\section{Sample selection and models Sample selection}

This study sets the time period 2010-2016 to control the effects of the US sub-prime mortgage crisis of $2007^{1}$ and, as shown in Table 1, begins with a sample of 6195 firm-year observations which were traded on the Korea Composite Stock Price Index (KOSPI) market. Firstly excluded are: (1) 1099 firm-year observations for financial institutions and (2) 217 firm-year observations closing in months other than December to keep the homogeneity of samples in industries and closing months. ${ }^{2}$ Moreover, eliminated were (3) 3048 firm-year observations that do not have ACs, (4) 335 firmyear observations that could not collect corporate governance data from the annual reports filed on the Korean Electronic Disclosure System (DART) (http:/ / dart.fss.or.kr) and (5) 337 firm-year observations for which financial data could not be obtained for this study from the FnGuide database (http://www.fnguide.com). This sample selection process resulted in a final sample of 1159 firm-year observations. All continuous variables are winsorised at $1 \%$ and $99 \%$ of each variable in order to prevent a wrong outcome, which can be a result of its outliers.

\section{Models}

To test Hypotheses 1 and 2, I estimate the following regression models, which follow prior research into AF (Abbott et al., 2003; Beck \& Mauldin, 2014; Huang et al., 2014; Loukil, 2014; Park, 2012, 2019; Redmayne et al., 2011):

1.The National Bureau of Economic Research (2010) reports that the global economic recession which began in December of 2007 extended to June 2009.

2.Korean government requires financial companies to have stricter corporate governance structures, and thus the firms' practices in determining AC compensation may depend on their industry. Auditors' work compression can be affected by the firms' closing months, thus audit pricing may depend on closing months. 
TABLE 1: Sample selection.

\begin{tabular}{|c|c|}
\hline Sample description & $N$ \\
\hline Firm-year observations listed on the KOSPI market during 2010-2016 & 6195 \\
\hline (1) Excluded firm-year observations for financial institutions & (1099) \\
\hline (2) Excluded firm-year observations closing in months other than December & $(217)$ \\
\hline (3) Excluded firm-year observations which do not have an AC & (3048) \\
\hline $\begin{array}{l}\text { (4) Excluded firm-year observations with missing corporate governance data } \\
\text { such as audit and non-audit fees, AC characteristics and board composition }\end{array}$ & $(335)$ \\
\hline $\begin{array}{l}\text { (5) Excluded firm-year observations with missing financial data from FnGuide } \\
\text { database }\end{array}$ & $(337)$ \\
\hline Final sample & 1159 \\
\hline
\end{tabular}

Final sample

Note: The value in parentheses refer to the number of companies to be subtracted from the total sample.

AC, audit committee; KOSPI, Korea Composite Stock Price Index.

$\mathrm{MCAF}=\beta_{0}+\beta_{1} \mathrm{MCTACP}(\mathrm{MCAACP})+\beta_{2} \mathrm{ACBP}+$ $\beta_{3} \mathrm{MCTACP}(\mathrm{MCAACP}) \times \mathrm{ACBP}+$ Controls $+\varepsilon, \quad$ [Eqn 2]

Where:

- $\mathrm{MCAF}=$ mean-centring $\mathrm{AF}$ (the natural log of $\mathrm{AF}-$ AF mean)

- $\quad \mathrm{MCTACP}=$ mean-centring total AC pay (the natural log of total AC cash pay (TACP) - TACP mean)

- $\mathrm{MCAACP}=$ mean-centring average $\mathrm{AC}$ pay (the natural log of average AC cash pay (AACP) - AACP mean)

- $\mathrm{ACBP}=$ dummy variable equal to 1 for an $\mathrm{AC}$ compliance with all best practices and 0 otherwise

- $\quad$ LTA = the natural log of total assets

- $\mathrm{RRI}=$ ratio of receivables and inventory to total assets

- SCS = square root of the number of consolidated subsidiaries

- $\mathrm{LEV}=$ ratio of total liabilities to total assets

- $\mathrm{ROA}=$ ratio of net income to total assets

- $\mathrm{CFL}=$ cash flows divided by total assets

- DLOSS = dummy variable equal to 1 for firms reporting a loss, 0 otherwise

- $\mathrm{DBIG}=$ dummy variable equal to 1 for firms using Big 4 auditors, 0 otherwise

- $\mathrm{ROD}=$ ratio of outside directors on board

- $\mathrm{DF}=$ dummy variable equal to 1 for initial year of the audit engagement, 0 otherwise

- $\mathrm{MSO}=$ managerial share ownership

- IND/YD = industry and year dummy variables

To alleviate the issue of multicollinearity between variables, the mean-centring audit fee (MCAF) variable is included as the dependent variable in equations. The MCAF variable is the value subtracted from the natural log of AF to AF mean for observations. Total cash pay and average cash pay per person are used to capture AC compensation and, similar to AF, the mean-centring compensation variables (MCTACP, MCAACP) as the outcome variables. If the level of compensation to ACs represents the level of demand for monitoring the financial reporting process, highly paid ACs would engage high-quality auditors, which would result in high $\operatorname{AF}\left(\beta_{1}>0\right)$. However, if the level of compensation represents the extent

to which ACs tolerate managers' opportunistic behaviour, highly paid ACs may engage low-quality auditors, which would result in low AF $\left(\beta_{1}<0\right)$. As argued in prior research (Abbott \& Parker, 2000; Abbott et al., 2003, 2004; Baxter \& Cotter, 2009; Beasley et al., 2000; Bedard et al., 2004; Hamdan et al., 2015; Kusnadi et al., 2016; Loukil, 2014; Park, 2019; Sultana et al., 2015; Vlaminck \& Sarens, 2015; Xie et al., 2003), the monitoring effectiveness of ACs will be higher when: (1) they are composed of only outside directors with (2) at least one finance or accounting expert and (3) they meet four times a year. The ACBP to capture effective $\mathrm{AC}$ is the dummy variable equal to 1 for ACs in compliance with all best practices and 0 otherwise. Effective ACs would engage high-quality auditors, and thus would pay higher $\operatorname{AF}\left(\beta_{2}>0\right)$. The interaction variables $(\mathrm{MCTACP}[\mathrm{MCAACP}] \times \mathrm{ACBP})$ are also included to capture the possible interactions between $\mathrm{AC}$ compensation and compliance with $\mathrm{AC}$ best practices on AF. If highly paid ACs and AC compliance with all best practices are complementary to one another in monitoring the management, $\beta_{1}$ and $\beta_{3}$ in Equation 2 will both be positive and significant. However, if they have conflicting interests in monitoring the management, then $\beta_{1}<0$ and $\beta_{3}>0$ in Equation 2.

Based on prior research that uses AF as audit quality (Abbott \& Parker, 2000; Abbott et al., 2003, 2004; Beck \& Mauldin, 2014; Huang et al., 2014; Loukil, 2014; Park, 2019), the predictions for the control variables in Equation 1 are as follows. Auditors' efforts and their ability to deal with complex business are increasingly required as firm size and firm complexity increase. Log of total asset (LTA) and SCS would positively affect $\mathrm{AF}\left(\beta_{3,5}>0\right)$. As the sum of accounts receivable and inventory increases, the firm's ability to generate cash declines and the obsolescence of inventory accelerates, resulting in higher audit risk. Ratio of receivables and inventory (RRI) would positively affect $\mathrm{AF}\left(\beta_{4}>0\right)$. Excessive debt and financial loss lead to poor financial health and increase the possibility of bankruptcy. Both LEV and DLOSS would positively affect $\operatorname{AF}\left(\beta_{6,9}>0\right)$. Good profitability and cash flow decrease audit risk because they may reduce managerial opportunistic incentives and lead to a healthy financial condition, whereas the financial factors that may represent firm complexity raise potential errors in financial reporting and more audit efforts can be demanded. ROA and CFL may or may not affect AF positively $\left(\beta_{7,8}>0\right.$ or $\left.\beta_{7,8}<0\right)$. Large audit firms generally are paid a high premium for audit quality, and independent boards prefer a high-quality auditor to complement their monitoring functions for management. DBIG and ROD would positively affect AF $\left(\beta_{10,11}>0\right) .^{3}$ Auditors in the initial year of audit engagement would be lenient of managers' opportunistic behaviour and offer a discount on audit prices to retain clients. DF would negatively affect $\mathrm{AF}\left(\beta_{12}<0\right)$. Managers' influence over companies usually increases with the proportion of their own shares. Korean managers could have a significant influence on auditor selection. They continue to exert efforts to escape from monitoring by auditors in order to pursue their own

3.The four major audit firms in Korea are Samil, Samjung, Han Young and Anjin, which have partnerships with foreign audit firms. However, there are no requirements in have partnerships with foreign audit firms. However, there are no requirements in
Korea on which auditors can actually perform assurance engagements for large companies. 
private goals. Managerial share ownership (MSO) would negatively affect $\mathrm{AF}\left(\beta_{13}<0\right)$. To control industries and times fixed effects, 12 industry dummy variables and 6-year dummy variables are included.

\section{Empirical results Descriptive statistics}

Panel A of Table 2 shows the descriptive statistics of the variables and Panel B presents the result showing whether $\mathrm{AF}$ and compensation for AC members differ across two groups: the group of firms whose ACs meet best practice versus the group of firms whose ACs do not meet best practice. Panel A shows that the mean and median of the MCAF are both 0.000 . The mean (median) of the meancentring total AC compensation (MCTACP) and average AC compensation (MCAACP) are 0.000 (0.166) and 0.000 (0.103), respectively. The ACs complying with all best practices (ACBP) accounts for $56.7 \%$ of the full sample and the sum of accounts receivable and inventories (RRI) occupies $21.4 \%$ of total assets. Debt size (LEV), net income (ROA) and operating cash flows (CFL) account for $47.1 \%, 5.2 \%$ and $5.5 \%$ of total assets, respectively. A total of $17.6 \%$ of the full sample report financial loss (DLOSS) and 89\% engage the big four auditors (DBIG). Also $49.3 \%$ of the board consists of outside directors (ROD) and $12.9 \%$ of auditors are in the initial year of audit engagement (DF). The mean (median) of the number of subsidiaries (SCS) and the equity owned by management (MSO) are $3.122(2.828)$ and 10\%, respectively. Panel B shows that mean-centring AF (MCAF), total AC compensation
(MCTACP) and average AC compensation (MCAACP) are higher for firms with ACs which meet all best practices, suggesting that those complying with best practice reinforce the positive relationship between AC compensation and AF.

Table 3 shows the Pearson correlations of primary variables. Consistent with expectations, MCAF is significantly and positively correlated with both MCTACP and MCAACP $(r=0.55 / 0.43, p<0.01)$, suggesting that consistent with prior studies (Barrier, 2002; Bierstaker et al., 2012; Rickling \& Sharma, 2017), highly paid ACs engage high-quality auditors. Mean-centring AF (MCAF) is also significantly and positively correlated with ACBP $(r=0.22, p<0.01)$, suggesting that ACs complying with best practices engage high-quality auditors. As expected, MCAF is significantly and positively correlated with LTA, RRI, SCS, LEV, ROA, CFL, DBIG and ROD, whereas it is negatively correlated with DF and MSO. Both MCTACP and MCAACP are significantly and positively correlated with ACBP $(r=0.17 / 0.08, p<0.01)$, revealing that ACs complying with best practice are paid more highly.

\section{Audit committee compensation, compliance with best practice and audit fees}

Panel A of Table 4 shows the results of the analysis of the relationship between $\mathrm{AC}$ compensation and $\mathrm{AF}$, and Panel $\mathrm{B}$ presents the results of the analysis of how the relationship between $\mathrm{AC}$ compensation and $\mathrm{AF}$ is moderated by $\mathrm{AC}$ compliance with all best practices.

TABLE 2: Descriptive statistics and the difference tests.

\begin{tabular}{|c|c|c|c|c|c|c|c|c|c|}
\hline \multirow[t]{3}{*}{ Variable } & \multicolumn{5}{|c|}{ Panel A: Descriptive statistics of the variables } & \multicolumn{4}{|c|}{$\begin{array}{l}\text { Panel B: Difference tests of audit fees and AC } \\
\text { compensation by AC compliance with best practices }\end{array}$} \\
\hline & \multirow[t]{2}{*}{ Mean } & \multirow[t]{2}{*}{ Std. Dev } & \multicolumn{3}{|c|}{$\%$} & \multirow[t]{2}{*}{$N$} & \multirow[t]{2}{*}{ MCAF } & \multirow[t]{2}{*}{ MCTACP } & \multirow[t]{2}{*}{ MCAACP } \\
\hline & & & $25 \%$ & Median & $75 \%$ & & & & \\
\hline MCAF & 0.000 & 0.957 & -0.790 & 0.000 & 0.669 & - & - & - & - \\
\hline Audit fees (KRW: thousand) & 371004 & 1521722 & 93000 & 205000 & 400000 & - & - & - & - \\
\hline MCTACP & 0.000 & 0.860 & -0.340 & 0.166 & 0.561 & - & - & - & - \\
\hline MCAACP & 0.000 & 0.769 & -0.339 & 0.103 & 0.460 & - & - & - & - \\
\hline Total AC pay (KRW: thousand) & 141600 & 108671 & 76000 & 126000 & 187000 & - & - & - & - \\
\hline Average AC pay (KRW: thousand) & 49309 & 43729 & 27000 & 42000 & 60000 & - & - & - & - \\
\hline ACBP & 0.567 & 0.496 & 0.000 & 1.000 & 1.000 & - & - & - & - \\
\hline LTA & 28.094 & 1.647 & 26.673 & 28.223 & 29.344 & - & - & - & - \\
\hline RRI & 0.214 & 0.144 & 0.101 & 0.197 & 0.317 & - & - & - & - \\
\hline SCS & 3.122 & 2.483 & 1.414 & 2.828 & 4.243 & - & - & - & - \\
\hline LEV & 0.471 & 0.213 & 0.299 & 0.503 & 0.617 & - & - & - & - \\
\hline ROA & 0.052 & 0.068 & 0.019 & 0.044 & 0.081 & - & - & - & - \\
\hline CFL & 0.055 & 0.079 & 0.010 & 0.051 & 0.097 & - & - & - & - \\
\hline DLOSS & 0.176 & 0.381 & 0.000 & 0.000 & 0.000 & - & - & - & - \\
\hline DBIG & 0.890 & 0.312 & 1.000 & 1.000 & 1.000 & - & - & - & - \\
\hline ROD & 0.493 & 0.131 & 0.400 & 0.500 & 0.571 & - & - & - & - \\
\hline DF & 0.129 & 0.336 & 0.000 & 0.000 & 0.000 & - & - & - & - \\
\hline MSO & 0.100 & 0.134 & 0.000 & 0.037 & 0.160 & - & - & - & - \\
\hline$A C B P=1$ & - & - & - & - & - & 657 & 0.166 & 11.706 & 10.598 \\
\hline$A C B P=0$ & - & - & - & - & - & 502 & -0.217 & 11.411 & 10.469 \\
\hline$t$-Value & - & - & - & - & - & 1159 & $7.578 * * *$ & $5.877 * * *$ & $2.829 * * *$ \\
\hline
\end{tabular}

KRW, South Korean Won; MCAF, mean-centring audit fees (the natural log of audit fees [AF] - AF mean); MCTACP, mean-centring total AC pay (the natural log of total AC cash pay [TACP] - TACP mean); MCAACP, mean-centring average AC pay (the natural log of average AC cash pay [AACP] - AACP mean); ACBP, the value of 1 for an AC complying with best practice and 0 otherwise; LTA, the natural log of total assets; RRI, ratio of receivables and inventory to total assets; SCS, square root of the number of consolidated subsidiaries; LEV, ratio of total liabilities to total assets; ROA, ratio of net income to total assets; CFL, cash flows divided by total assets; DLOSS, dummy variable with value of 1 for firm reporting a loss, 0 otherwise; DBIG, dummy variable with value of 1 for firms using Big 4 auditors, 0 otherwise; ROD, ratio of outside directors on board; DF, dummy variable with value of 1 for initial year of the audit engagement, 0 otherwise; MSO, managerial ownership. ***, the statistical significance of the $t$-Value at the $1 \%$ level. 
TABLE 3: Results of correlation analysis.

\begin{tabular}{|c|c|c|c|c|c|c|c|c|c|c|c|c|c|c|}
\hline Variable & MCAF & МСТАСР & MCAACP & ACBP & LTA & RRI & SCS & LEV & ROA & CFL & DLOSS & DBIG & ROD & DF \\
\hline MCAF & 1.00 & - & - & - & - & - & - & - & - & - & - & - & - & - \\
\hline МСТАСР & $0.55 * * *$ & 1.00 & - & - & - & - & - & - & - & - & - & - & - & - \\
\hline MCAACP & $0.43 * * *$ & $0.86 * * *$ & 1.00 & - & - & - & - & - & - & - & - & - & - & - \\
\hline ACBP & $0.22 * * *$ & $0.17 * * *$ & $0.08 * * *$ & 1.00 & - & - & - & - & - & - & - & - & - & - \\
\hline LTA & $0.79 * * *$ & $0.62 * * *$ & $0.50 * * *$ & $0.27 * * *$ & 1.00 & - & - & - & - & - & - & - & - & - \\
\hline RRI & $0.21 * * *$ & $-0.29 * * *$ & $-0.22 * * *$ & $-0.10 * * *$ & $-0.34 * * *$ & 1.00 & - & - & - & - & - & - & - & - \\
\hline SCS & $0.61 * * *$ & $0.39 * * *$ & $0.32 * * *$ & $0.10 * * *$ & $0.60 * * *$ & $-0.31 * * *$ & 1.00 & - & - & - & - & - & - & - \\
\hline LEV & $0.13 * * *$ & 0.06 & 0.00 & 0.04 & $0.23 * * *$ & $0.16 * * *$ & 0.02 & 1.00 & - & - & - & - & - & - \\
\hline ROA & $0.13 * * *$ & 0.04 & $0.07 * *$ & -0.02 & 0.01 & $0.11 * * *$ & -0.01 & $-0.36 * * *$ & 1.00 & - & - & - & - & - \\
\hline CFL & $0.18 * * *$ & $0.06 * *$ & $0.07 * *$ & 0.02 & $0.05 *$ & 0.01 & 0.04 & $-0.28 * * *$ & $0.61 * * *$ & 1.00 & - & - & - & - \\
\hline DLOSS & -0.03 & -0.04 & -0.05 & $0.06 *$ & 0.02 & $-0.06 * *$ & 0.00 & $0.39 * * *$ & $-0.52 * * *$ & $-0.34 * * *$ & 1.00 & - & - & - \\
\hline DBIG & $0.30 * * *$ & $0.37 * * *$ & $0.31 * * *$ & $0.12 * * *$ & $0.37 * * *$ & $-0.15 * * *$ & $0.23 * * *$ & $-0.06 * *$ & $0.15^{* * *}$ & $0.12 * * *$ & $-0.15 * * *$ & 1.00 & - & - \\
\hline ROD & $0.36 * * *$ & $0.29 * * *$ & $0.16 * * *$ & $0.17 * * *$ & $0.41 * * *$ & $-0.15 * * *$ & $0.23 * * *$ & $0.14 * * *$ & -0.03 & 0.03 & 0.03 & $0.16 * * *$ & 1.00 & - \\
\hline DF & $-0.06 *$ & -0.02 & 0.00 & -0.00 & -0.01 & -0.02 & $-0.07 * *$ & $0.08 * * *$ & -0.04 & -0.01 & 0.01 & $-0.07 * *$ & -0.06 & 1.00 \\
\hline
\end{tabular}

Note: The figures in the above table indicate the Pearson correlation coefficients.

MCAF, mean-centring audit fees (the natural log of audit fees [AF] - AF mean); MCTACP, mean-centring total AC pay (the natural log of total AC cash pay [TACP] - TACP mean); MCAACP, meancentring average AC pay (the natural log of average AC cash pay [AACP] - AACP mean); ACBP, the value of 1 for an AC complying with best practice and 0 otherwise; LTA, the natural log of total assets; RRI, ratio of receivables and inventory to total assets; SCS, square root of the number of consolidated subsidiaries; LEV, ratio of total liabilities to total assets; ROA, ratio of net income to total assets; CFL, cash flows divided by total assets; DLOSS, dummy variable with value of 1 for firm reporting a loss, 0 otherwise; DBIG, dummy variable with value of 1 for firms using Big 4 auditors, 0 otherwise; ROD, ratio of outside directors on board; DF, dummy variable with value of 1 for initial year of the audit engagement, 0 otherwise; MSO, managerial ownership.

***, $p<0.01 ; * *, p<0.05 ; *, p<0.10$ (all two-tailed tests).

TABLE 4: Audit committee compensation, compliance with best practices and audit fees.

\begin{tabular}{|c|c|c|c|c|c|c|c|c|}
\hline \multirow[t]{2}{*}{ Panel } & \multirow[t]{2}{*}{ Variable } & \multirow[t]{2}{*}{ Pred. sign } & \multicolumn{3}{|c|}{ МСТАСР } & \multicolumn{3}{|c|}{ MCAACP } \\
\hline & & & Estimate & $t$-Value & Variable & Estimate & $t$-Value & Variable \\
\hline \multirow{19}{*}{$\begin{array}{l}\text { Panel A: Effect of AC } \\
\text { compensation on } \\
\text { audit fees: Equation } 1\end{array}$} & Intercept & \pm & -11.877 & $-35.198 * * *$ & - & -11.553 & $-32.185 * * *$ & - \\
\hline & MCTACP & + & 0.100 & $3.340 * * *$ & - & - & - & - \\
\hline & MCAACP & + & - & - & - & 0.060 & $3.123 * * *$ & - \\
\hline & ACBP & + & 0.044 & $1.706^{*}$ & - & 0.057 & $2.205^{* *}$ & - \\
\hline & LTA & + & 0.383 & $30.790 * * *$ & - & 0.374 & $28.460 * * *$ & - \\
\hline & RRI & + & 0.296 & $2.693 * * *$ & - & 0.239 & $2.193 * * *$ & - \\
\hline & SCS & + & 0.083 & $12.650 * * *$ & - & 0.083 & $12.653^{* * *}$ & - \\
\hline & LEV & + & 0.167 & $2.240 * *$ & - & 0.211 & $2.821 * * *$ & - \\
\hline & ROA & + & 0.479 & $1.859 *$ & - & 0.459 & $1.783^{*}$ & - \\
\hline & CFL & + & 0.954 & $4.847 * * *$ & - & 0.934 & $4.744 * * *$ & - \\
\hline & DLOSS & + & 0.075 & $1.875^{*}$ & - & 0.064 & 1.599 & - \\
\hline & DBIG & + & 0.046 & 1.040 & - & 0.044 & 0.986 & - \\
\hline & ROD & + & 0.231 & $2.237 * *$ & - & 0.300 & $2.939 * * *$ & - \\
\hline & MSO & - & -0.497 & $-4.787 * * *$ & - & -0.467 & $-4.478 * * *$ & - \\
\hline & IND & \pm & - & - & Yes & - & - & Yes \\
\hline & YD & \pm & - & - & Yes & - & - & Yes \\
\hline & Adjusted $R^{2}$ & $\mathrm{n} / \mathrm{a}$ & - & - & $79.2 \%$ & - & - & $79.2 \%$ \\
\hline & $F$-Value & $n / a$ & - & - & $138.425 * * *$ & - & - & $138.210 * * *$ \\
\hline & $N$ & $n / a$ & - & - & 1159 & - & - & 1159 \\
\hline \multirow{9}{*}{$\begin{array}{l}\text { Panel B: Effect of AC } \\
\text { compliance with best } \\
\text { practices: Equation } 2\end{array}$} & MCTACP & + & 0.041 & $1.725^{*}$ & - & - & - & - \\
\hline & MCAACP & + & - & - & - & 0.010 & 0.388 & - \\
\hline & ACBP & + & 0.085 & $1.687^{*}$ & - & 0.057 & $2.252^{* *}$ & - \\
\hline & MCTACP $\times$ ACBP & + & 0.127 & $2.309 * *$ & - & - & - & - \\
\hline & MCAACP $\times$ ACBP & + & - & - & - & 0.116 & $3.394 * * *$ & - \\
\hline & Controls & \pm & - & - & Yes & - & - & Yes \\
\hline & Adjusted $R^{2}$ & $\mathrm{n} / \mathrm{a}$ & - & - & $78.7 \%$ & - & - & $79.4 \%$ \\
\hline & $F$-Value & $\mathrm{n} / \mathrm{a}$ & - & - & $134.781 * * *$ & - & - & $135.500 * * *$ \\
\hline & $N$ & $\mathrm{n} / \mathrm{a}$ & - & - & 1159 & - & - & 1159 \\
\hline
\end{tabular}

MCAF, mean-centring audit fees the natural log of audit fees [AF] - AF mean); MCTACP, mean-centring total AC pay the natural log of total AC cash pay [TACP] - TACP mean); MCAACP, mean-centring average AC pay the natural log of average AC cash pay [AACP] - AACP mean); ACBP, the value of 1 for an AC complying with best practice and 0 otherwise; LTA, the natural log of total assets; RRI, ratio of receivables and inventory to total assets; SCS, square root of the number of consolidated subsidiaries; LEV, ratio of total liabilities to total assets; ROA, ratio of net income to total assets; CFL, cash flows divided by total assets; DLOSS, dummy variable with value of 1 for firm reporting a loss, 0 otherwise; DBIG, dummy variable with value of 1 for firms using Big 4 auditors, 0 otherwise; ROD, ratio of outside directors on board; DF, dummy variable with value of 1 for initial year of the audit engagement, 0 otherwise; MSO, managerial ownership; IND, industry dummy variable; YD, year dummy variable; Pred. sign, predicted sign; n/a, not applicable.

$* * *, p<0.01 ; * *, p<0.05 ; *, p<0.10$ (all two-tailed tests).

Panel A shows that the coefficients on MCTACP and MCAACP are both significant and positive $(\beta=0.100 / 0.060$, both $p<0.01$ ), implying that highly paid ACs engage high- quality auditors, and hence the level of compensation represents the requirement to monitor the financial reporting process. The coefficients of $A C B P$ are also significant and 
positive $(\beta=0.044 / 0.057, p<0.10 / 0.05)$, showing that ACs complying with best practice prefer high-quality auditors. As expected, LTA, RRI, SCS, LEV, ROA, CFL, DLOSS and ROD are significantly and positively associated with MCAF, whereas DF and MSO are significantly and negatively associated with MCAF. As Panel B shows, the coefficients of the interactive terms, MCTACP $\times \mathrm{ACBP}$ and MCAACP $\times$ ACBP, are significant and positive $(\beta=0.127 / 0.116$, $p<0.05 / 0.01)$, indicating that the positive association between compensation for ACs and AF is reinforced for firms whose ACs meet best practice. These results suggest that highly paid ACs and AC compliance with best practice complement each other in enhancing audit quality. The importance of incentive compensation schemes in order to secure the expertise of AC members has been highlighted. Thus, if companies do not pay appropriate compensation to AC members, they would have difficulty operating ACs effectively (Barrier, 2002; Bierstaker et al., 2012; Rickling \& Sharma, 2017). Moreover, not paying appropriate compensation to AC members would negatively affect their activity. Leading Korean companies (e.g. KB Group [2010], Woori Group [2011]) have paid compensation for independent directors in the form of regular pay and meeting participation allowances. The compensation scheme for AC members should be designed to encourage them to do their best (Barrier, 2002; Carcello, Hermanson, \& Ye, 2011).

The finding that $\mathrm{AC}$ compensation is positively associated with $\mathrm{AF}$ does not support Hypothesis 1 . However, the positive interaction between $\mathrm{AC}$ compensation and $\mathrm{AC}$ compliance with best practices on AF can be evidence supporting Hypothesis 2. Overall, highly paid ACs engage high-quality auditors in order to complement their monitoring function of management, and this relationship is strengthened when ACs meet best practices.

\section{Audit committee compensation, compliance with best practice and managerial opportunism}

If the interaction of $\mathrm{AC}$ compensation with compliance with best practice is really linked to AC effectiveness, thereby leading to the engagement of a high-quality auditor, it would limit opportunistic earnings management. Earnings management has a positive aspect of delivering future corporate value to the capital market, but there are also negative aspects that are used to pursue managers' private interests (Gul, Chen, \& Tsui, 2003).

Prior research argues that managers seek to avoid reporting financial losses and decreases in earnings to increase their compensation and reduce dismissal risk (Burgsthahler \& Dichev, 1997; Burgsthahler \& Eames, 2003; Das, Shroff, \& Zhang, 2009; Park, 2015, 2017). To investigate how the relationship between AC compensation and the opportunistic achievement of earnings goals is moderated by AC compliance with best practice, the following logistic regression model is estimated:

$$
\begin{aligned}
\operatorname{ALR}(\mathrm{AED})= & \beta_{0}+\beta_{1} \mathrm{MCTACP}+\beta_{2} \mathrm{ACBP}+\beta_{3} \mathrm{MCTACP} \times \\
& \mathrm{ACBP}+\beta_{4} \mathrm{LTA}+\beta_{5} \mathrm{RRI}+\beta_{6} \mathrm{SCS}+ \\
& \beta_{7} \mathrm{LEV}+\beta_{8} \mathrm{ROA}+\beta_{9} \mathrm{CFL}+\beta_{10} \mathrm{DLOSS}+ \\
& \beta_{11} \mathrm{DBIG}+\beta_{12} \mathrm{ROD}+\beta_{13} \mathrm{DF}+\beta_{14} \mathrm{MSO}+ \\
& \beta_{15-26} \mathrm{IND}+\beta_{27-32} \mathrm{YD}+\varepsilon,
\end{aligned}
$$

Where:

- $\mathrm{ALR}=$ dummy variable with value of 1 if the firm's nondiscretionary earnings (net income - DA) fall short of zero but the firms report profits

- $\mathrm{AED}=$ dummy variable with value of 1 if the firm's nondiscretionary earnings fall short of earnings in the prior year but the firms report earnings increase.

The firms whose earnings are positive but whose nondiscretionary accruals fall short of zero would have had an incentive to avoid reporting a financial loss. Moreover, the firms whose earnings increase over the prior year, but whose non-discretionary accruals fall short of earnings in the prior year would have had an incentive to avoid a decrease in earnings. Two dummy variables to capture managers' opportunistic behaviours that avoid reporting financial losses or decreases in earnings are included as the dependent variables (ALR, AED). Specifically, ALR is the dummy variable with value of 1 if the firms report profits but their non-discretionary earnings (net income - discretionary accruals) fall short of zero and 0 otherwise. AED is the dummy variable with value of 1 if the firms report earnings increase but their non-discretionary earnings fall short of earnings in the prior year, and 0 otherwise. The discretionary accruals, which represent earnings management, are estimated by the modified Jones models (Dechow, Sloan, \& Sweeney, 1995). ${ }^{4}$ If high AC compensation and compliance with best practice can limit opportunistic earnings management, the coefficients of MCTACP and ACBP would be both significant and negative $\left(\beta_{1,2}<0\right)$. Moreover, if high AC compensation interacts with compliance with best practice to limit opportunistic earnings management, the coefficients on interaction terms of MCTACP $\times$ ACBP would be both significant and negative $\left(\beta_{3}<0\right)$.

Large companies that are in complex business environments are more likely to be involved in earnings management to meet stakeholder expectations, and thus LTA and SCS would positively affect opportunistic behaviours of managers $\left(\beta_{4,6}>0\right)$. The obsolescence of inventory and poor financial condition could incite management to inflate earnings, and thus RRI, LEV and DLOSS would be positively associated with income-increasing discretionary accruals used to achieve earnings goals $\left(\beta_{5,7,10}>0\right)$. Because good accounting performance, strong cash flows, high-quality auditors and board independence could reduce managerial incentives to inflate earnings, ROA, CFL, DBIG and ROD would negatively affect income-increasing discretionary accruals for earnings goals $\left(\beta_{8,9,11,12}<0\right)$. Auditors in initial year of the audit

4.They define residuals $(\varepsilon)$ of the following cross-sectional model as discretionary

accruals: $\mathrm{TA}_{t} / \mathrm{A}_{\mathrm{t}-1}=\beta_{0}+\beta_{1}\left(1 / \mathrm{A}_{t-1}\right)+\beta_{2}\left(\Delta \mathrm{REV}_{t}-\Delta \mathrm{AR}\right) / \mathrm{A}_{t-1}+\beta_{3}\left(\mathrm{PPE}_{t} / \mathrm{A}_{t-1}\right)+\varepsilon$,

where $T A$ is the total accruals in year $t ; \Delta R E V$ is the change in sales in year $t ; \mathrm{A}_{t-1}$ is the total assets in year $t-1 ; \triangle \mathrm{AR}$ is the change in receivables in year $t$ and $\mathrm{PPE}_{t}$ is the gross property plant and equipment in year $t$. 
engagement tend to tolerate management' opportunistic behaviours to keep their clients, and thus DF would positively affect income-increasing discretionary accruals used to achieve earnings goals $\left(\beta_{13}>0\right)$. Because managers are more likely to pursue private benefits as their influence on companies increase, MSO would positively affect incomeincreasing discretionary accruals for earnings goals $\left(\beta_{14}>0\right)$.

Table 5 shows the results of the analysis of how the relationship between $\mathrm{AC}$ compensation and income-increasing discretionary accruals used to achieve earnings goals is moderated by AC compliance with best practices. The coefficients of MCTACP are both significant and negative $(\beta=-2.147 /-0.525, p<0.01 / 0.10)$ and those of $\mathrm{ACBP}$ are also significant and negative for ALR $(\beta=-1.153, p<0.05)$. These results indicate that a highly paid $\mathrm{AC}$ and $\mathrm{AC}$ compliance with best practices are both effective in reducing managerial opportunism. Moreover, the coefficients on the interaction terms, MCTACP $\times$ ACBP, are also both significant and negative, indicating that the negative relationship between $\mathrm{AC}$ compensation and opportunistic earnings management is strengthened in firms whose ACs meet all best practices. Consistent with expectations, LTA, RRI, SCS and LEV are positively associated with the achievement of earnings goals, whereas ROA, CFL and DBIG are negatively associated with it. The results for MCAACP are similar to those for MCTACP; thus, for brevity, that report is omitted.

TABLE 5: Logistic regression of the achievement of earnings goals on audit committee compensation and audit committee compliance with best practices: Equation 3.

\begin{tabular}{|c|c|c|c|c|c|c|c|}
\hline \multirow[t]{2}{*}{ Variable } & \multirow{2}{*}{$\begin{array}{c}\text { Pred. } \\
\text { sign }\end{array}$} & \multicolumn{3}{|c|}{ ALR } & \multicolumn{3}{|c|}{ AED } \\
\hline & & Estimate & Wald & Variable & Estimate & Wald & Variable \\
\hline Intercept & \pm & -12.673 & $10.060 * * *$ & - & -7.215 & $7.601 * * *$ & - \\
\hline MCTACP & - & -2.147 & $7.074 * * *$ & - & -0.525 & $2.966 *$ & - \\
\hline ACBP & - & -1.153 & $4.129 * *$ & - & -0.704 & 2.177 & - \\
\hline $\begin{array}{l}\text { MCTACP } \times \\
\text { ACBP }\end{array}$ & - & -1.586 & $4.790 * * *$ & - & -0.741 & $3.051 *$ & - \\
\hline LTA & + & 0.472 & $10.481 * * *$ & - & 0.227 & $5.634 * *$ & - \\
\hline RRI & + & 1.553 & 1.704 & - & 1.967 & $6.088 * *$ & - \\
\hline SCS & + & 0.240 & $11.305 * * *$ & - & 0.029 & 0.386 & - \\
\hline LEV & + & 3.432 & $15.394 * * *$ & - & -0.621 & 1.203 & - \\
\hline ROA & - & -20.852 & $20.487 * * *$ & - & 10.347 & $24.655 * * *$ & - \\
\hline CFL & - & -1.854 & $26.136 * * *$ & - & -15.348 & $86.378 * * *$ & - \\
\hline DLOSS & + & -9.067 & 0.000 & - & -1.914 & 2.365 & - \\
\hline DBIG & - & -1.624 & $11.304 * * *$ & - & -0.880 & $7.711 * * *$ & - \\
\hline ROD & - & 0.253 & 0.051 & - & -0.070 & 0.009 & - \\
\hline DF & + & -0.158 & 0.163 & - & -0.371 & 1.587 & - \\
\hline MSO & + & 0.703 & 0.475 & - & -0.261 & 0.125 & - \\
\hline IND & \pm & - & - & Yes & - & - & Yes \\
\hline YD & \pm & - & - & Yes & - & - & Yes \\
\hline $\begin{array}{l}\text { Nagelkerke } \\
R^{2}\end{array}$ & $\mathrm{n} / \mathrm{a}$ & - & - & $71.3 \%$ & - & - & $22.8 \%$ \\
\hline$\chi^{2}$ & $n / a$ & - & - & $634.244 * * *$ & - & - & $166.493 * * *$ \\
\hline$N$ & $\mathrm{n} / \mathrm{a}$ & - & - & 1159 & - & - & 1159 \\
\hline
\end{tabular}

ALR, dummy variable with value of 1 if the firm's non-discretionary earnings fall short of zero but the firms report profits; AED, dummy variable with value of 1 if the firm's non-discretionary earnings fall short of earnings in the prior year but the firms report earnings increase; MCTACP, mean-centring total AC pay (the natural log of total AC cash pay [TACP] - TACP mean); ACBP, the value of 1 for an AC complying with best practice and 0 otherwise; LTA, the natural log of tota assets; RRI, ratio of receivables and inventory to total assets; SCS, square root of the number of consolidated subsidiaries; LEV, ratio of total liabilities to total assets; ROA, ratio of net income to total assets; CFL, cash flows divided by total assets; DLOSS, dummy variable with value of $1 \mathrm{for}$ firm reporting a loss, 0 otherwise; DBIG, dummy variable with value of 1 for firms using Big auditors, 0 otherwise: $R O D$, ratio of outside directors on board; $D F$, dummy variable with value 1 for initial dummy variable; YD, year dummy variable; Pred. sign, predicted sign; $\mathrm{n}$ a, not applicable.

***, $p<0.01 ; * *, p<0.05 ; *, p<0.10$ (all two-tailed tests).
Overall, the results show that the interactions between $\mathrm{AC}$ compensation and AC compliance with best practice make ACs more effective in limiting managers' opportunistic behaviours. Considering the results of Table 4, AF increased by ACs' efforts represent high-quality audits. ${ }^{5}$

In addition, as described in the 'Background' section, ACs in companies with assets fewer than 2 trillion won are voluntary ACs, which may be driven by the desire of stakeholders to increase management transparency. To check the robustness of the results in terms of the formation of ACs, the sample was divided into two sub-samples with a mandatory AC $(n=555)$ and a voluntary AC $(n=604)$, and a separate analysis was performed for each sub-sample. However, the results of this study did not differ in the type of AC formation (not reported).

\section{Discussion}

Despite over three decades of research into the relationship between AC compensation and financial reporting quality, prior studies have been inconclusive. While some research finds a negative association between them (Archambeault et al., 2008; Jensen, 1993; Keune \& Johnstone, 2015; Magilke et al., 2009), there are other works revealing a positive association between AC compensation and the quality of financial reporting (Barrier, 2002; Bierstaker et al., 2012; Rickling \& Sharma, 2017). Audit committees have economic incentives that could affect auditor selection. Underpinned by agency theory, short-term stock options for AC can align with increasing AC short-term pay-off and thus promote a preference for low-quality auditors. By contrast, long-term stock options for AC can align with enhancing shareholders' long-term welfare and thus promote a preference for highquality auditors. There are still conflicting results on the relationship between stock-based AC compensation and financial reporting quality (Archambeault et al., 2008; Keune \& Johnstone, 2015). However, as discussed in Korea background, the effect of cash only compensation on financial reporting quality has no bearing on the length of the compensation period (Bierstaker et al., 2012; Magilke et al., 2009; Rickling \& Sharma, 2017). Instead, cash-based AC compensation would better inspire AC to effectively monitor financial reporting (Barrier, 2002). As in prior research, AC effectiveness improves when ACs meet all best practice guidelines and effective ACs are more likely to engage high-quality auditors. Thus, it would be important to understand whether the role of cash-based $\mathrm{AC}$ compensation in determining $\mathrm{AF}$ is consistent with prior studies focusing on effective ACs. Although effective ACs have been studied extensively in audit research, this construct has not been applied to verify the relationship between cashbased AC compensation and audit quality. Taken together, I extend these bodies of knowledge by providing insight on how cash-based AC compensation is related to the propensity to engage high-quality auditors and whether this relationship is more pronounced for firms with ACs which comply with best practice.

5.The results of the analysis for ACS complying with Korean regulations related to the composition are also similar to those for ACs complying with best practices. 
The findings of Table 4 are interpreted as evidence that the fee-increasing efforts by highly paid ACs lead to the engagement of high-quality auditors, consistent with prior works (Barrier, 2002; Bierstaker et al., 2012; Rickling \& Sharma, 2017). Moreover, their efforts, which are strengthened when ACs are more effective, are interpreted that cash-based AC compensation and compliance with best practices are complementary to enhance audit quality. The findings of Table 5 suggest that cash-based AC compensation positively interacts with $\mathrm{ACs}^{\prime}$ compliance with best practices in limiting managers' opportunistic behaviours. It could be evidence that AF increased by highly paid ACs represent high-quality audits. The findings of Table 4 therefore are robust to the consideration of managers' opportunistic behaviours. Contrary to stock-based AC compensation, cashbased AC compensation is not related to earnings surprise wealth effects (Rickling \& Sharma, 2017). It would play a crucial role in aligning interests of ACs and stakeholders on audit quality by promoting objectivity of auditor selection conducted by AC members.

This study contributes to audit research. Firstly, as prior research has neglected the interaction of financial incentives for ACs and their compliance with best practice, this study fills the research gap by examining the cash-based AC compensation serving as a catalyst, leading to effective ACs carrying out best practice. Secondly, this study provided empirical findings to add value to research into the association between AC compensation and AF. As limited, mixed or conflicting evidence exists in the literature, this study provides empirical evidence in a Korean context to support that cash-based AC compensation mitigates agency problems that can occur between AC members, managers and external stakeholders (Barrier, 2002; Bierstaker et al., 2012; Rickling \& Sharma, 2017). The findings thus provide the interesting insights that can be applicable to countries with requirements relating to the compensation schemes for ACs or the formation of the AC.

\section{Conclusion}

Auditing is a part of efficient capital markets, and audit quality has received much attention in the wake of highprofile accounting scandals such as Enron and Arthur Andersen. However, there could be the divergence of interests between ACs and stakeholders with respect to audit quality when ACs are exposed to economic issues (Archambeault et al., 2008; Keune \& Johnstone, 2015; Magilke et al., 2009). While much attention has been paid to $\mathrm{AC}$ best practices and $\mathrm{AF}$, the interaction between $\mathrm{AC}$ compensation and AC compliance with best practices on AF has been little understood to date. This study unites three research streams: research on AC compensation, research on AC best practices and research on AF. I complement the prior literature by investigating how the relationship between the amount of cash compensation for $\mathrm{AC}$ and audit quality captured by AF is moderated by AC compliance with best practices which represents effective AC. There is a positive association between AC compensation and AF. Further, the positive relationship between the two is shown to be more pronounced for firms with ACs which comply with best practice, suggesting that AC compensation levels and compliance with best practice guidelines are complementary in enhancing audit quality.

Some avenues of future research can be proposed. Firstly, future researchers can apply my model and approaches in the public sector (Redmayne et al., 2011). As there are some differences in the effectiveness and scope of AC monitoring between the private and public sector, researchers will benefit from this study to investigate both public and private sectors. Secondly, as this study context is limited in Korea, a comparative study between Asian nations and/or international study may provide further research validity for this study. Thirdly, future research should find a combination of stock options and cash compensation to maximise AC effectiveness. The optimal AC compensation schemes can be the main key to enhancing corporate governance (Barrier, 2002; Bierstaker et al., 2012; Carcello et al., 2011).

\section{Acknowledgements Competing interests}

The author declares that he has no financial or personal relationships that may have inappropriately influenced him in writing this article.

\section{Author's contributions}

I declare that I am the sole author of this research article.

\section{Ethical consideration}

This article followed all ethical standards for carrying out research without direct contact with human or animal subjects.

\section{Funding}

This work was supported by the Soonchunhyang University Research Fund.

\section{Data availability statement}

Data sharing is not applicable to this article as no new data were created or analysed in this study.

\section{Disclaimer}

The views and opinions expressed in this article are those of the authors and do not necessarily reflect the official policy or position of any affiliated agency of the authors.

\section{References}

Abbott, L.J., \& Parker, S. (2000). Auditor selection and audit committee characteristics. Auditing: Journal of Practice \& Theory, 19(2), 47-66. https://doi.org/10.2308/ aud.2000.19.2.47

Abbott, L.J., Parker, S., Peters, G.F., \& Raghunandan, K. (2003). The association between audit committee characteristics and audit fees. Auditing: Journal of Practice \& Theory, 22(2), 17-32. https://doi.org/10.2308/aud.2003.22.2.17 
Abbott, L.J., Parker, S., \& Peters, G.F. (2004). Audit committee characteristics and restatements. Auditing: Journal of Practice \& Theory, 23(1), 69-87. https://doi. restatements. Auditing: Journal
org/10.2308/aud.2004.23.1.69

Archambeault, D., DeZoort, F.T., \& Hermanson, D.R. (2008). Audit committee incentive compensation and accounting restatements. Contemporary Accounting Research, 25(4), 965-992. https://doi.org/10.1506/car.25.4.1

Barrier, M. (2002). The compensation balance. Internal Auditor, 59(3), 42-47.

Baxter, P., \& Cotter, J. (2009). Audit committees and earnings quality. Accounting and Finance, 49(2), 267-290. https://doi.org/10.1111/j.1467-629X.2008.00290.x

Beasley, M.S., Carcello, J.V., Hermanson, D.R., \& Lapides, P.D. (2000). Fraudulent financial reporting: Consideration of industry traits and corporate governance mechanisms. Accounting Horizon, 14(4), 14-21. https://doi.org/10.2308/acch. 2000.14.4.441

Beck, M.J., \& Mauldin, E.G. (2014). Who's really in charge? Audit committee versus CFO power and audit fees. The Accounting Review, 89(6), 2057-2085. https://doi. org/10.2308/accr-50834

Bedard, J., Chtourou, S.M., \& Courteau, L. (2004). The effect of audit committee expertise, independence, and activity on aggressive earnings management. Auditing: Journal of Practice \& Theory, 23(2), 13-36. https://doi.org/10.2308/ aud.2004.23.2.13

Bierstaker, J.L., Cohen, J.R., DeZoort, F.T., \& Hermanson, D.R. (2012). Audit committee compensation, fairness, and the resolution of accounting disagreements. Auditing: A Journal of Practice \& Theory, 31(2), 131-150. https://doi.org/10.2308/ ajpt-10238

Blue Ribbon Committee (BRC). (1999). Audit committee characteristics and restatements: A study of the efficacy of certain Blue Ribbon Committee recommendations. New York: New York Stock Exchange and National Association of Securities Dealers.

Burgsthahler, D.C., \& Dichev, I. (1997). Earnings management to avoid earnings decreases and losses. Journal of Accounting and Economics, 24(1), 99-126. https://doi.org/10.1016/S0165-4101(97)00017-7

Burgsthahler, D.C., \& Eames, M.J. (2003). Earnings management to avoid losses and earnings decreases: Are analysts fooled? Contemporary Accounting Research, 20(2), 253-294. https://doi.org/10.1506/BXXP-RGTD-HOPM-9XAL

Carcello, J.V., Hermanson, D.R., \& Ye, Z. (2011). Corporate governance research in accounting and auditing: Insights, practice implications, and future research directions. Auditing: A Journal of Practice \& Theory, 30(3), 1-31. https://doi.org/ 10.2308/ajpt-10112

Cheng, P., Su, L., \& Zhu, X. (2012). Managerial ownership, board monitoring and firm performance in a family-concentrated corporate environment. Accounting and Finance, 52(4), 1061-1081. https://doi.org/10.1111/j.1467-629X.2011.00448.x

Choi, J.H., Jeon, K.A., \& Park, J.I. (2004). The role of audit committees in decreasing earnings management: Korea evidence. International Journal of Accounting, Auditing and Perfor
IJAAPE.2004.004142

Christensen, B., Omer, T., Sharp, N., \& Shelley, M. (2013). Pork bellies and public company audits: Have audits once again become just another commodity? Working paper. Texas A\&M University.

Das, S., Shroff, P.K., \& Zhang, H. (2009). Quarterly earnings patterns and earnings management. Contemporary Accounting Research, 26(3), 797-831. https://doi. org/10.1506/car.26.3.7

Dechow, P.M., Sloan, R.G., \& Sweeney, A.P. (1995). Detecting earnings management The Accounting Review, 70(2), 193-225. https://www.jstor.org/stable/248303

Doogar, R., Rowe, S., \& Sivadasan, P. (2015). Asleep at the wheel (again)? Bank audits during the financial crisis. Contemporary Accounting Research, 32(1), 358-391. https://doi.org/10.1111/1911-3846.12101

Fama, E.F. (1980). Agency problems and the theory of the firm. The Journal of Political Economy, 88(2), 288-307. https://doi.org/10.1086/260866

Fama, E.F., \& Jensen, M. (1983). The separation of ownership and control. Journal of Law and Economics, 26(2), 301-325. https://doi.org/10.1086/467037

Fichtner, J.R. (2010). The recent international growth of mandatory audit committee requirements. International Journal of Disclosure and Governance, 7(3), 227-243. https://doi.org/10.1057/jdg.2009.29

Goodwin-Steward, J., \& Kent, P. (2006). 'Relation between external audit fees, audit committee characteristics and internal audit. Accounting and Finance, 46(3), 387-404. https://doi.org/10.1111/j.1467-629X.2006.00174.x

Gul, F.A., Chen, C., \& Tsui, J. (2003). Discretionary accounting accruals, managers' incentives, and audit fees. Contemporary Accounting Research, 20(3), 441-464 https://doi.org/10.1506/686E-NF2J-73X6-G540

Hamdan, A.M.M., Mushtaha, S.M.S., \& Al-Sartawi, A.A.M. (2015). The audit committee characteristics and earnings quality: Evidence from Jordan. Australasian Accounting Business \& Finance Journal, 7(4), 51-80. https://doi.org/10.14453/ aabfj.v7i4.5

Huang, H.W., Parker, R.J., Anderson, Y.C., \& Lin, Y.H. (2014). CEO turnover and audit pricing. Accounting Horizons, 28(2), 297-312. https://doi.org/10.2308/acch-50706
Jensen, M. (1993). The modern industrial revolution: Exit and the failure of internal control system. Journal of Finance, 48(3), 831-880. https://doi.org/10.1111/ j.1540-6261.1993.tb04022.x

Keune, M., \& Johnstone, K. (2015). Audit committee incentives and the resolution of detected misstatements. Auditing: A Journal of Practice \& Theory, 34(4), 109-137. https://doi.org/10.2308/ajpt-51080

Klein, A. (2002). Audit committee, board of directors characteristics, and earnings management. Journal of Accounting and Economics, 33(3), 375-400. https://doi. org/10.1016/S0165-4101(02)00059-9

Knechel, W.R. (2015). Audit research in the wake of SOX. Managerial Auditing Journal, 30(8/9), 706-726. https://doi.org/10.1108/MAJ-08-2015-1233

Knechel, W.R., Krishnan, G., Pevzner, M., Shefchik, L., \& Velury, U. (2013). Audit quality: Insights from the academic literature. Auditing: A Journal of Practice \& Theory, 32(1), 385-421. https://doi.org/10.2308/ajpt-50350

Korea Corporate Governance Service (KCGS). (2007). Guidelines for the evaluation of the board of directors. Seoul: KCGS.

Kusnadi, Y., Leong, K., Suwardy, T., \& Wang, J. (2016). Audit committees and financial reporting quality in Singapore. Journal of Business Ethics, 139(1), 197-214. https://doi.org/10.1007/s10551-015-2679-0

La Porta, R., Lopez-de-Silanes, F., \& Shleifer, A. (1999). Corporate ownership around the world. Journal of Finance, 54(2), 471-518. https://doi.org/10.1111/0022-1082. world.

Loukil, L. (2014). Audit committees and audit fees: An empirical study in large French listed companies. Journal of Accounting - Business \& Management, 21(2), 36-53.

Magilke, M.J., Mayhew, B.W., \& Pike, J.E. (2009). Are independent audit committee members objective? Experimental evidence. The Accounting Review, 84(6) 1959-1981. https://doi.org/10.2308/accr.2009.84.6.1959

National Association of Corporate Directors (NACD). (2000). Report of the NACD Blue Ribbon Commission on audit committees. Washington, DC: NACD.

National Bureau of Economic Research (NBER). (2010). Business cycle dating committee. Cambridge, MA: NBER.

$\mathrm{Ng}$, C.Y.M. (2005). An empirical study on the relationship between ownership and performance in a family-based corporate environment. Journal of Accounting, Auditing and Finance, 20(2), 121-146. https://doi.org/10.1177/0148558X0502 000202

Park, B.-J. (2012). The study of the relation between ownership structure and audit fee. Korean Accounting Information Review, 30(1), 1-28.

Park, B.-J. (2015). Client importance and earnings quality: An analysis of the moderating effect of managerial incentives for target beating versus auditors' incentives to avoid reputational losses and litigation. Spanish Journal of Finance and Accounting, 44(4), 427-457. https://doi.org/10.1080/02102412.2015.1076634

Park, B.-J. (2017). Auditors' economic incentives and the sensitivity of managerial pay to accounting performance. Australian Accounting Review, 27(4), 382-399. https://doi.org/10.1111/auar.12154

Park, B.-J. (2019). Audit committees and managerial influence on audit quality: 'voluntary' versus 'mandatory' approach to corporate governance. Australian Accounting Review, 29(1), 266-280. https://doi.org/10.1111/auar.12263

Public Oversight Board (POB). (1993). A special report by the public oversight board of the SEC practice section, AICPA: Issues confronting the accounting profession: Litigation, self-regulation, standards, public confidence, professional practice. Washington, DC: Public Oversight Board.

Rickling, M.F., \& Sharma, D.S. (2017). Audit committee cash compensation and propensity of firms to beat earnings by a large margin: Conditional effects of CEO power and agency risks. International Journal of Auditing, 21(3), 304-323. https:// doi.org/10.1111/ijau.12098

Redmayne, N.B., Bradbury, M.E., \& Cahan, S.F. (2011). The association between audit committees and audit fees in the public sector. International Journal of Auditing, 15(2), 301-315. https://doi.org/10.1111/j.1099-1123.2011.00436.x

Sharma, V.D., Sharma, D.S., \& Ananthanarayanan, U. (2011). Client importance and earnings management: The moderating role of audit committees. Auditing A Journal of Practice \& Theory, 30(3), 125-156. https://doi.org/10.2308/ajpt-10111

Sultana, N., Singh, H., \& Van der Zahn, J. (2015). Audit committee characteristics and audit report lag. International Journal of Auditing, 19(2), 72-87. https://doi.org/ 10.1111/ijau.12033

Vlaminck, N.D., \& Sarens, G. (2015). The relationship between audit committee characteristics and financial statement quality: Evidence from Belgium. Journal of Management \& Governance, 19(1), 145-166. https://doi.org/10.1007/s10997013-9282-5

Xie, B., Davidson, W.N., \& DaDalt, P.J. (2003). Earnings management and corporate governance: The roles of the board and the audit committee. Journal of Corporate Finance, 9(3), 295-316. https://doi.org/10.1016/S0929-1199(02)00006-8

Zaman, M., Hudaib, M., \& Haniffa, R. (2011). Corporate governance quality, audit fees and non-audit services fees. Journal of Business Finance \& Accounting, 38(1-2), 165-197. https://doi.org/10.1111/j.1468-5957.2010.02224.x 